\title{
Earnings Smoothing and Bankruptcy Risk in Liquidating Private Firms
}

\author{
Nor Afifah Shabani (Corresponding author) \\ Department of Accounting and Finance \\ Faculty of Management, Universiti Teknologi Malaysia, 81110 Johor, Malaysia \\ E-mail: norafifah85@gmail.com
}

\begin{abstract}
Saudah Sofian
Department of Accounting and Finance

Faculty of Management, Universiti Teknologi Malaysia, 81110 Johor, Malaysia

E-mail:saudah@utm.my
\end{abstract}

Received: March 18, 2018 Accepted: April 10, 2018 Published: June 1, 2018

doi:10.5296/ajfa.v10i1.12904 URL: https://doi.org/10.5296/ajfa.v10i1.12904

\begin{abstract}
Keywords: earnings Smooth earnings are preferred by managers and creditors because they represent a stable business operations as well as low loan default risks and thus creditors reward firms which have smooth earnings with better loan covenant terms and lower interest rates. Nonetheless, recent literature shows that earnings smoothing in public firms is associated with stock price crash risk. Using Altman Z" score to measure firm's specific bankruptcy risk, this study examines the association between accrual earnings smoothing and bankruptcy risk in liquidating private firms in UK and finds that earnings smoothing significantly negatively affects those firms' bankruptcy risk. The finding implies that financially distressed firms engage with less earnings smoothing, possibly because they do not have the opportunity to engage in accrual earnings smoothing anymore. Nonetheless, further examination shows that these firms engage less with earnings smoothing because they are being monitored by external creditors, indicated by significantly high leverage during the last period before they are being liquidated.
\end{abstract}

Keywords: smoothing, private firms, bankruptcy risk, liquidation, distressed firms, creditors 


\section{Introduction}

Earnings smoothing is the result of management's attempts to make earnings look less variable over time (Goel \& Thakor, 2003). While managers in public firms may engage in earnings smoothing activities for various reasons such as to gain higher compensation contract in the future, to secure bonus which are tied to current performance, or to manage firm's credit ratings (Goel \& Thakor, 2003; Jung, Soderstrom, \& Yang, 2013; Moses, 1987), managers in private firms smooth earnings mainly to meet creditors' demand (Bigus \& Häfele, 2016; Gassen \& Fülbier, 2015).

Due to the nature of private firms, they do not have access to public debt. As a consequence, private firm's source of financing is limited to creditors such as banks and trade creditors. Hence, external creditors have direct and indirect influence on private firm's financial reporting (Hope \& Vyas, 2017). For instance, creditors view smooth earnings as the signal of a stable and viable business operation. They classify firms with smooth earnings as low loan default risk (Demerjian, Donovan, \& Lewis-Western, 2017) and reward this type of firm with lower interest rate (Amiram \& Owens, 2018; Gassen \& Fülbier, 2015). Therefore, managers of private firms are inherently obliged to report smooth earnings to enjoy a better loan covenant and lower interest rate from creditors.

In contrast with the view of creditors that smooth earnings signals business' viability (e.g. Tucker \& Zarowin 2006; Amiram \& Owens 2017; Dou et al. 2013), recent literature finds that earnings smoothing is associated with stock price crash risk. Studies by Chen et al. (2017) and Khurana et al. (2017) find that both artificial and real earnings smoothing are positively associated with stock price crash risk. These findings are consistent with the view that earnings smoothing encourages manager's opportunistic behavior and helps obfuscates the true underlying performance of a firm.

Consequently, the findings of Chen et al. (2017) and Khurana et al. (2017) raise the following question: Does earnings smoothing has the same impact on private firms - destroying firm's value and putting firm at risk? Unfortunately, the same inference cannot be made about private firms since private firms do not have stock price crash risk. This study, therefore, intends to fill the gap by examining the effect of earnings smoothing behavior on private firm's bankruptcy risk. Firms that are in liquidation process are chosen as the sample group because these firms are facing bankruptcy. Therefore, if earnings smoothing are indeed related to bankruptcy risk in private firms, the relation will be highlighted in the examination.

Using firm-specific bankruptcy risk, as measured by Altman (1983) Z" score, this study finds that among the financially distressed firms, firms with smoother earnings is found to be significantly negatively associated with bankruptcy risk. The finding implies that financially distressed firms engage with less accrual earnings smoothing because they have run out of opportunities to manipulate earnings via accrual earnings smoothing. Nonetheless, further examination shows that these firms engage less with earnings smoothing because they are being monitored by external creditors, indicated by significantly high leverage during the last year before they are being liquidated as compared to two or three years prior to the liquidation event. 
This study makes three important contributions to the body of knowledge regarding earnings smoothing and private firms. Firstly, this study contributes to the literature that investigates the attributes of earnings smoothing. Previous research on earnings smoothing have been focusing on public firms (Shabani \& Sofian, 2018). Only few research examine the attributes of earnings smoothing in private firms such as Bigus and Häfele (2016) and Gassen and Fulbier (2015). To our knowledge, this is the first paper that examines earnings smoothing behavior in financially distressed private firms. The findings highlight that, contrary to the findings in public firms, earnings smoothing does not contribute to private firm's value being destroyed. Secondly, this study provides additional evidence on the attributes of financial reporting for private firms. This study finds that private firms' behavior in reporting their earnings is highly influenced by their creditors - financially distressed firms with higher leverage engage with lesser earnings smoothing, similar to the findings by Gassen and Fülbier (2015). Finally, this study contributes to the debate of earnings smoothing as information signaling versus information garbling. This study finds evidence that financially distressed firms do not use earnings smoothing to garble information - because they cannot use accruals to smooth earnings anymore.

\section{Literature review}

Earnings smoothing is part of earnings management, where managers report manipulated earnings - which does not accurately represent economic earnings for the reporting period. Earnings smoothing involves intertemporal smoothing of reported earnings related to economic earnings, to make earnings look less variable over time. The literature shows that managers smooth earnings for either one of two main reasons: as information signaling or information garbling.

Earnings smoothing is regarded as information signaling when managers use earnings smoothing as a vehicle to communicate private information about firm's future earnings to outside stakeholders (Arya, Glover, \& Sunder, 2003; Kirschenheiter \& Melumad, 2002; Sankar \& Subramanyam, 2001). Under this view, earnings smoothing plays an important role in bridging the information opacity between management and other stakeholders (Goel \& Thakor, 2003) and therefore earnings smoothing is considered very useful to the stakeholders like participants in public market, creditors and credit rating agencies. Public market participants reward firms which report smooth earnings with lower cost of equity (Francis, LaFond, Olsson, \& Schipper, 2005) and lower cost of debt (bond) (Li \& Richie, 2016). Similarly, creditors and credit rating agencies also reward firms which have smoother income with lower cost of debt and better credit rating; they believe that smooth earnings signals reduced the probability of default risks (Amiram \& Owens, 2018; Jung et al., 2013; Trueman $\&$ Titman, 1988). Given these findings, it comes to no surprise when Graham et al. (2005) find that vast majority of top management prefer smooth earnings path.

On the other hand, earnings smoothing is considered as information garbling when earnings smoothing distorts information and consequently leads to higher information opacity. Bhattacharya et al. (2003) argue that earnings smoothing resulted in reported earnings not depicting the true underlying economic performance of the firm, and hence reducing the 
informativeness of reported earnings and increasing information opacity. In line with this view, Jayaraman (2008) documents that earnings smoothing is associated with higher bid-ask spreads and the probability of informed trading while Cahan et al. (2008) and Maffet (2012) find that firms in countries with weak investor protection use earnings smoothing for opportunistic reasons.

Based on the extant literature, earnings smoothing as information garbling is associated with manager's opportunistic behaviour - managers smooth earnings for personal gain such as to meet bonus target (Das, Hong, \& Kim, 2013; Gaver, Gaver, \& Austin, 1995; Healy, 1985; Moses, 1987) or for job security (Grant, Markarian, \& Parbonetti, 2009; Ronen \& Sadan, 1981). According to Ronen and Sadan (1981), manager's compensation and tenure is associated with business risk. Therefore, to secure their job tenure and compensation, managers smooth earnings to manage shareholders' perception on firm's risk, since shareholders perceive lower earnings volatility as lower business risk.

\subsection{Earnings smoothing and bankruptcy risk}

Besides personal reasons, managers may also smooth earnings for professional reason - to maximize firm's value. Firm's value is dependent on shareholders' perception; asymmetric information theory argues that investor's estimate is unbiased and 'best' based on the information they have. Therefore, it is considered rational for shareholders to require earnings outcome that is consistent with their expectation (Acharya \& Lambrecht, 2015). In addition, shareholders infer reported earnings to be of high quality, and value firm higher, if earnings surprise is smaller (i.e. reported earnings is closer to expected earnings) (Kirschenheiter \& Melumad, 2002). Accordingly, managers have to report an earnings figure that corresponds to outside shareholders' expectation rather than true income.

In line with the view that managers smooth earnings to maximize firm's value, earnings smoothing also provides managers with the opportunity to withhold bad news. During good times, managers manage earnings downward, giving them opportunity to conceal bad news in the future. Graham et al. (2005) report that managers withhold bad news; in case things might turn around in the future, they may be able to bury the bad news. Similarly, Kothari et al. (2009) find that managers withhold bad news to a certain threshold, but disclosed good news as soon as possible. While their intention may be good (i.e. to increase firm's value), earnings smoothing may lead to firm's value being destroyed and putting firm at the risk of bankruptcy, especially when the news is particularly bad and managers cannot hoard the news any longer. Using firm-specific stock price crash, Chen et al. (2017) discover that earnings smoothing can lead to abrupt decline in stock price, due to managers dumping all bad news at once. Likewise, Khurana et al. (2017) find that real earnings smoothing influences stock price crash risk since real earnings smoothing facilitates bad news hoarding, allows poor-performing projects to continue, conceal resource diversion, and enables ineffective risk management for extended periods.

Based on the discussion above, it is clear that earnings smoothing, either artificial or real, is related to the firm's value being destroyed. While the evidence on the association between earnings smoothing and destroyed firm's value for public firms may be examined through 
stock price crash risk, it is impossible to do the same with private firms since private firms do not have stock price information. Alternatively, the effect of earnings smoothing on private firms may be examined using firm-specific bankruptcy risk.

\subsection{Earnings smoothing behaviour in private firms}

Research on earnings management behaviour in private firms finds that private firms report lower earnings quality as well as higher earnings management, as compared to their public firms' counterpart, (e.g. Ball \& Shivakumar 2005; Burgstahler et al. 2006; Coppens \& Peek 2005) due to the absence of capital market pressure. Ball and Shivakumar (2005) find that private firms in the UK report less timely earnings and they suggest this finding indicates that creditors of private firms might be using alternative source of information, instead of earnings information, to assess the private firms' business stability and ability to repay loan. Nonetheless, Hope et al. (2011) find that private firms with audited financial statement experience significantly lower financial constraint in accessing credit. This finding implies that creditors of private firms use financial reports in their loan decision process. In addition, Gassen and Fulbier (2015) find that creditors of private firms demand smooth earnings and that firms with smoother earnings receive lower interest rate for their loan.

While earnings smoothing is beneficial to private firms (i.e. they receive lower interest rate), it is argued that earnings smoothing poses a higher threat to private firm's sustainability, especially when firms can no longer hoard bad news. When bad news ruptured, private firms are exposed to the risk of breaching debt covenants, which could lead to increased bankruptcy risk. Violation of debt covenants resulted in control rights of management reverting to creditors, providing creditors the opportunity to take action (e.g. renegotiation, winding up petition) to protect the value of their claim (Aghion \& Bolton, 1992). Hence, prior research find that firms that are in distressed, or closer to the violation of debt covenants have more incentives to manage their earnings (Franz, HassabElnaby, \& Lobo, 2014; Saleh \& Ahmed, 2005; Sweeney, 1994). Based on the discussion above, it is hypothesized that:

H1: Earnings smoothing is associated with bankruptcy risk in private firms, ceteris paribus.

H2: Private firms engage more earnings smoothing as they are getting more distressed, ceteris paribus.

\section{Data and research design}

The data for this study is collected from Financial Analysis Made Easy (FAME) database. The initial data selection process acquires financial data from 3,962 private firms in UK which were in liquidation process during 2012-2017. Among these firms, 802 firms have to be removed because they their last account data were prior to 2012. Year 2012 has been chosen as the cut-off date because the main variable, Smooth, requires at least three years financial data prior to the announcement date, and to make sure that the financial crisis in 2008 does not affect the result of this study. After eliminating firms with missing data, the final sample is left with 372 firms. 


\subsection{Research design}

Following Chen et al. (2017) and Khurana et al. (2017), the model used to test H1 is as follows:

$$
\begin{aligned}
& \text { FIRM - SPECIFIC BANKRUPTCY RISK } K_{i, t}=\alpha_{0}+\beta_{1} \text { SMOOTH }_{i, t-1}+\sum \gamma * \text { CONTROLS }_{i, t-1}+ \\
& \text { INDUSTRY FIXED - EFFECTS }+\varepsilon_{i, t}
\end{aligned}
$$

The dependent variable, FIRM-SPECIFIC BANKRUPTCY RISK, is calculated using Altman (1983) Z" score model and the term is multiplied by minus one so that larger values imply higher bankruptcy risk.

$$
Z \text { " score }=6.56 * X_{1}+3.26 * X_{2}+6.72 * X_{3}+1.05 * X_{4}
$$

Where:

$\mathrm{X}_{1}$ is working capital scaled by total assets

$\mathrm{X}_{2}$ is retained profit scaled by total assets

$\mathrm{X}_{3}$ is EBIT scaled by total assets

$\mathrm{X}_{4}$ is shareholders' equity scaled by total assets

The main variable of interest, SMOOTH, is measured using a model established by Gassen and Fulbier (2015) as follows:

$$
\text { SMOOTH }=S T D_{-} N E T_{-} I N C O M E_{i} / S T D_{-} C A S H_{-} F L O W_{i}
$$

Where:

STD_NET_INCOME is standard deviation of net income, scaled by lagged total assets

STD_CASH_FLOW is standard deviation of cash flow from operation, scaled by lagged total assets

The measure of earnings smoothing is calculated based on firm-specific time-series of data, requiring at least three annual observations for each firm, before the announcement date. As a result, there is only one SMOOTH observation per firm in the sample. The term is multiplied by minus one so that larger values imply higher earnings smoothing.

Prior studies (e.g. Altman 1983; Altman \& Sabato 2007; Bellovary et al. 2007) find that a firm's bankruptcy risk is associated with high leverage, low profitability, low liquidity and high insolvency. Therefore, LEVERAGE, PROFITABILITY, LIQUIDITY, and SOLVENCY are used as controlling variables. Firm's LEVERAGE is calculated using current liabilities, divided with shareholder's equity; PROFITABILITY is calculated using EBITDA, divided with total assets; LIQUIDITY is measured by dividing cash with total assets; and SOLVENCY is measured by dividing current liabilities with inventory. INDUSTRY FIXED-EFFECT is represented by two digit SIC code. 


\section{Findings}

\subsection{Descriptive analysis}

Table 1 presents the structure of this cross-sectional sample. The sample largely consists of firms in construction and wholesale (39.8 percent), public and administration (12.6 percent) and manufacturing of refined goods (10.5 percent) industries. About one-third of the firms in the sample (36 percent) received the notice for liquidation in 2017. Number of firms that received the notice for liquidation reduced from year to year. For example, the number of firms in 2017 is 134, but the number of firms in 2016 is 107 . The main reason for this trend is due to the technical limitation. While the firms might receive the notice for liquidation in 2015, for example, their last account date is not necessarily in 2014 or 2015. Rather, they might have last account date of two or more years prior to the notice for liquidation. As the model requires financial data of at least three years consecutively, and the exclusion of year 2008 due to financial crisis, many firms have to be dropped from the sample list, especially those firms which receive notice for liquidation in earlier periods.

Table 2 exhibits distributional properties and correlations between the dependent and independent variables in the sample. The size of average sample firms, as measured by total assets, is around £6.6 million (median), which is similar to previous studies focusing on private firms in UK (e.g. Ball \& Shivakumar 2005). Smooth variable indicates that majority of the sample firms (69.9 percent) has earnings that are less volatile than cash flows (i.e. SMOOTH > -1). Z" score indicates that majority of the sample firms (76.01 percent) have high risk for bankruptcy (i.e. Z" SCORE $>-2.9$ ). This is as expected because the sample firms consists of firms that are in the process of liquidation; either voluntary by members or creditors, or by court orders. Consistent with this notion, many of the sample firms have negative net income (49.7 percent), negative EBIT (48.1 percent) and negative CFO (30.6 percent). On average, the sample firms are highly leveraged (current liabilities to equity of 112.9 percent) and highly insolvent (current liabilities to inventory of 483.7 percent), indicating that these firms are highly dependent on external debt to finance their operation and that they are having difficulties to repay their debts. They also have low profitability (ROA of 4.2 percent) and low liquidity (cash to total liabilities of 4.9 percent). 


\section{Macrothink}

Asian Journal of Finance \& Accounting

ISSN 1946-052X

2018, Vol. 10, No. 1

Table 1. Tabulation of sample based on industry and liquidation status year

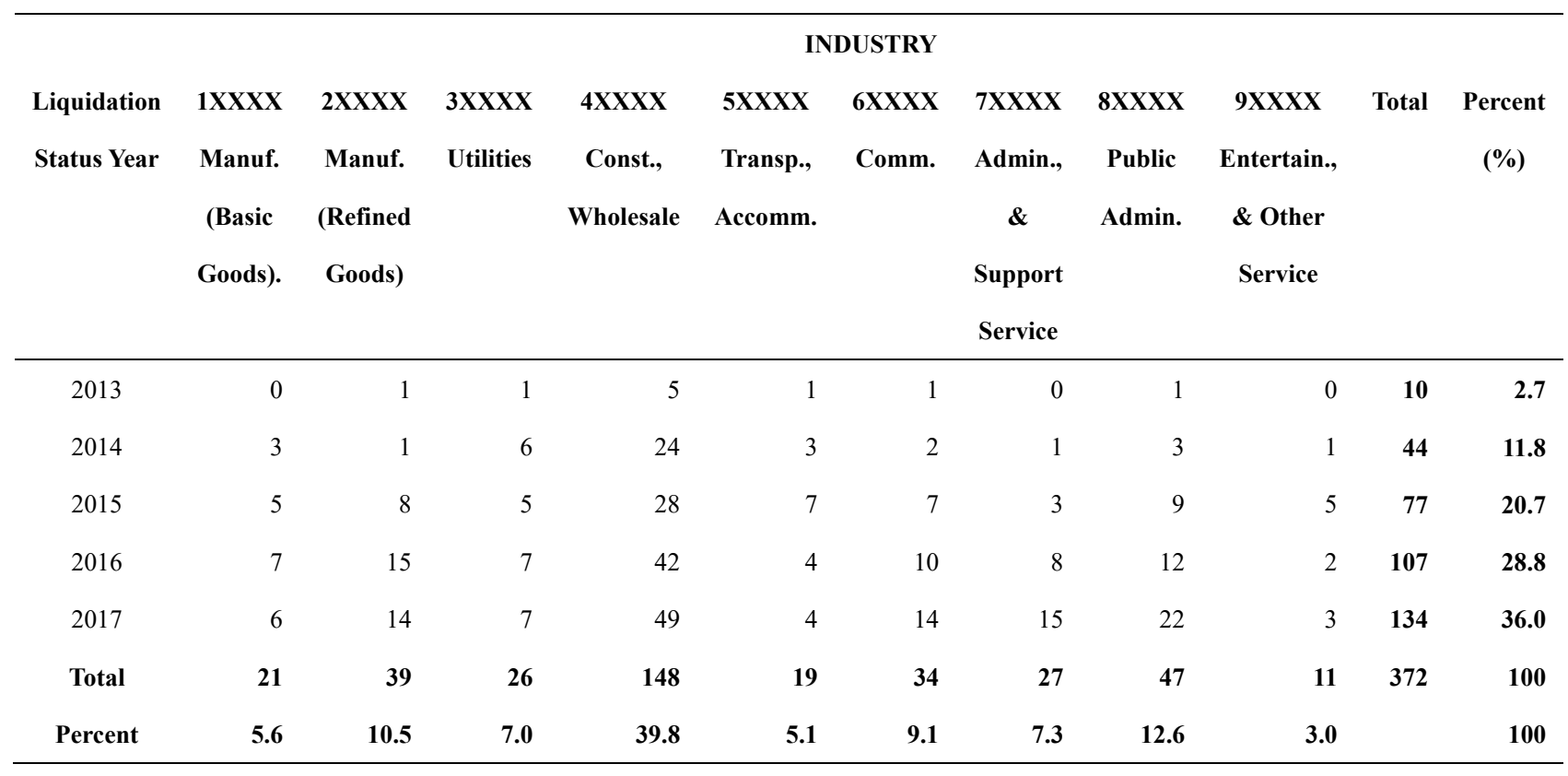

Table 2. Descriptive statistics

\begin{tabular}{|c|c|c|c|c|c|}
\hline Variable & Mean & $\begin{array}{l}\text { Standard } \\
\text { Deviation }\end{array}$ & $1^{\text {st }}$ Quartile & $2^{\text {nd }}$ Quartile & $3^{\text {rd }}$ Quartile \\
\hline Z" SCORE & -2.352 & 74.093 & -2.833 & -0.692 & 1.145 \\
\hline SМООТН & -1.378 & 2.962 & -1.227 & -0.569 & -0.272 \\
\hline TOTAL ASSETS ( $£$ '000) & $44,091.740$ & $210,316.000$ & $3,776.612$ & $6,599.725$ & $15,373.500$ \\
\hline$P P E(£$ ‘000) & $11,847.000$ & $69,460.940$ & 351.380 & $1,158.000$ & $3,602.000$ \\
\hline INVENTORY (£'O00) & $3,238.282$ & $9,787.318$ & 143.000 & 735.624 & $2,218.000$ \\
\hline DEBTORS (£ '000) & $4,424.354$ & $12,651.540$ & 449.000 & $1,430.500$ & $3,151.000$ \\
\hline EBIT (£ ‘000) & $1,144.658$ & $96,424.360$ & -544.944 & 13.448 & 441.611 \\
\hline NET INCOME (£ '000) & $1,310.894$ & $95,637.920$ & -533.352 & 15.221 & 375.708 \\
\hline CFO (£'000) & $3,249.167$ & $24,247.550$ & -156.921 & 329.500 & $1,544.000$ \\
\hline NEG INCOME (\%) & 0.497 & 0.501 & 0.000 & 0.000 & 1.000 \\
\hline LEVERAGE & 727.760 & $14,007.480$ & 0.135 & 1.129 & 3.436 \\
\hline PROFITABILITY & -0.150 & 2.450 & -0.011 & 0.042 & 0.109 \\
\hline LIQUIDITY & 1.159 & 11.763 & 0.008 & 0.049 & 0.218 \\
\hline SOLVENCY & 155.642 & $1,238.959$ & 1.913 & 4.837 & 23.62 \\
\hline
\end{tabular}


Continued

\begin{tabular}{|c|c|c|c|c|c|c|c|c|c|c|c|c|c|c|}
\hline \multicolumn{15}{|c|}{ PANEL B: CORRELATIONS } \\
\hline Variable & A & B & C & $\mathbf{D}$ & $\mathbf{E}$ & $\mathbf{F}$ & G & $\mathbf{H}$ & $\mathbf{I}$ & $\mathbf{J}$ & $\mathbf{K}$ & $\mathbf{L}$ & $\mathbf{M}$ & $\mathbf{N}$ \\
\hline A: Z” SCORE & & -0.023 & 0.015 & 0.007 & -0.008 & -0.007 & -0.017 & -0.017 & 0.000 & -0.004 & 0.004 & 0.580 & -0.006 & 0.012 \\
\hline B: SMOOTH & -0.243 & & -0.243 & -0.168 & -0.034 & -0.217 & 0.109 & 0.108 & -0.202 & -0.178 & -0.173 & -0.015 & 0.032 & -0.064 \\
\hline C: TOTAL ASSETS & 0.012 & -0.083 & & 0.410 & 0.181 & 0.720 & 0.602 & 0.603 & 0.615 & 0.016 & 0.271 & 0.019 & -0.012 & 0.261 \\
\hline$D: P P E$ & 0.236 & -0.135 & 0.556 & & 0.237 & 0.241 & -0.002 & -0.004 & 0.144 & 0.100 & 0.630 & 0.009 & 0.003 & 0.031 \\
\hline E: INVENTORY & -0.105 & -0.032 & 0.372 & 0.129 & & 0.292 & -0.100 & -0.104 & -0.013 & 0.083 & 0.023 & -0.010 & -0.019 & -0.039 \\
\hline F: DEBTORS & -0.087 & 0.081 & 0.424 & 0.169 & 0.323 & & 0.438 & 0.445 & 0.428 & 0.012 & 0.051 & 0.015 & -0.018 & 0.019 \\
\hline G: EBIT & -0.645 & 0.206 & 0.027 & -0.116 & 0.060 & 0.115 & & 0.998 & 0.531 & -0.095 & -0.053 & -0.010 & 0.000 & -0.005 \\
\hline H: NET INCOME & -0.296 & 0.190 & 0.386 & 0.214 & 0.049 & 0.257 & 0.622 & & 0.487 & -0.098 & -0.026 & 0.038 & -0.007 & 0.058 \\
\hline I: CFO & -0.026 & -0.010 & 0.316 & 0.213 & 0.164 & 0.241 & 0.189 & 0.203 & & -0.092 & 0.144 & 0.018 & -0.015 & 0.131 \\
\hline J: NEG INCOME & 0.318 & -0.275 & -0.159 & -0.091 & 0.052 & -0.119 & -0.538 & -0.806 & -0.267 & & 0.082 & -0.174 & 0.093 & -0.019 \\
\hline K: LEVERAGE & 0.051 & 0.155 & -0.011 & -0.034 & 0.120 & 0.271 & 0.132 & 0.144 & 0.022 & -0.180 & & 0.003 & -0.005 & -0.004 \\
\hline L:PROFITABILITY & -0.371 & 0.140 & 0.125 & 0.098 & -0.029 & 0.160 & 0.657 & 0.639 & 0.350 & -0.674 & 0.167 & & 0.004 & 0.006 \\
\hline M: LIQUIDITY & -0.487 & 0.058 & 0.004 & -0.177 & 0.001 & -0.036 & 0.236 & 0.230 & 0.027 & -0.170 & -0.277 & 0.148 & & -0.011 \\
\hline$N: S O L V E N C Y$ & 0.320 & -0.035 & 0.102 & 0.194 & -0.722 & 0.093 & -0.093 & -0.084 & 0.045 & 0.067 & 0.008 & 0.076 & -0.146 & \\
\hline
\end{tabular}

Table 2 presents descriptive statistics for the sample firms. In Panel B, Pearson correlations are shown above and Spearman correlations are shown below the diagonal. Variables are as defined in Appendix A.

Panel B of Table 2 reports the correlation of the variables. Pearson correlations are presented above and Spearman correlations are presented below the diagonal. The correlations between dependent and independent variables are generally low to moderate. Although there are a few independent variables (such as net income and EBIT) that show high correlations due to mechanic reasons, further examination reveals that these relations do not result in multicollinearity issue (i.e. Variance Inflation Factor or $\mathrm{VIF}<4$ ).

\subsection{Regression analysis}

Table 3 presents the regression results for $\mathrm{H} 1$ - the association between earnings smoothing and bankruptcy risk. The main independent variable, SMOOTH, is measured using Model 3. The regression results show that earnings smoothing is negatively and significantly affecting bankruptcy risk, rejecting null hypothesis for $\mathrm{H} 1$. The results suggest that firms with higher bankruptcy risk smooth less. The result is similar with previous research which find firms with higher earnings smoothing has lower likelihood of spurious technical default (Demerjian et al., 2017). This finding implies that financially distressed firms have run out of chances to garble information via accrual earnings smoothing.

Additional regression analyses; SMOOTH being measured with four and five years' data (using unbalanced panel), find similar results to the result of SMOOTH using three years data. However, the value of the coefficient and $t$ for SMOOTH using and five years data are higher than three years data. The value of R-squared is slightly higher using four years data $(98.5$ 
percent) as compared to three years data ( 95.5 percent), but reduces significantly for SMOOTH using five years data (57.8 percent). Based on the regression results, SMOOTH variable using three years data is the best to explain the relation between earnings smoothing and bankruptcy risk as compared to using four and five years data because more samples are included in the analysis, and therefore the result is more generalizable.

The regression results in Table 3 also show that firms with lower PROFITABILITY and lower LIQUIDITY are associated with higher bankruptcy risk, and the relations are statistically significant. The results also show that firms with higher LEVERAGE, and higher INSOLVENCY are associated with higher bankruptcy risk; however the relations are not statistically significant.

To test $\mathrm{H} 2$ - to examine whether private firms engage in more earnings smoothing as they are getting more distressed, paired t-test of a balanced panel of 173 samples, is used. Table 4 presents the results between earnings smoothing and bankruptcy risk-related variables, using data of one, two and three years prior to liquidation. The paired t-test finds weak evidence that firms engage with less earnings smoothing as they are getting more distressed. Therefore null hypothesis for $\mathrm{H} 2$ - private firms do not engage in more earnings smoothing as they are getting more distressed, is not rejected. Further examination (Table 5) shows that this relation is due to the monitoring effect from creditors. Regression analysis shows that private firms with more leverage have lower earnings smoothing.

Table 3. Earnings smoothing behavior and bankruptcy risk

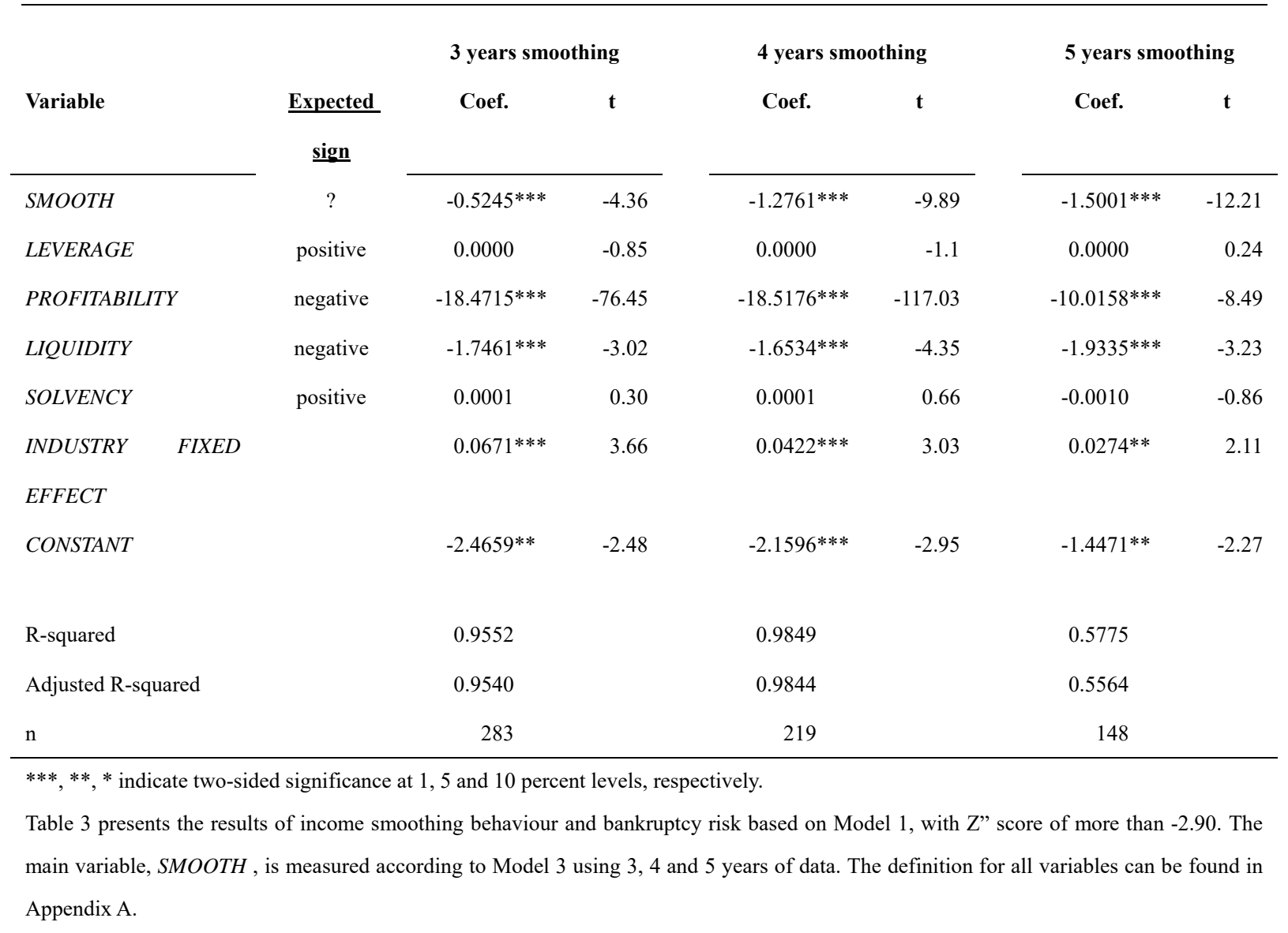


Table 4. Earnings smoothing behaviour prior to liquidation

\begin{tabular}{|c|c|c|c|c|c|c|}
\hline & $\begin{array}{r}1 \text { year prior } \\
\text { (A) }\end{array}$ & 2 years prior (B) & $\begin{array}{r}3 \text { years prior } \\
\text { (C) }\end{array}$ & & & \\
\hline$\underline{\text { Variable }}$ & Mean & $\underline{\text { Mean }}$ & $\underline{\text { Mean }}$ & $\underline{\operatorname{Diff}(\mathrm{A}-\mathrm{B})}$ & $\underline{\text { Diff }(A-C)}$ & $\underline{\operatorname{Diff}(B-C)}$ \\
\hline SMOOTH & -1.4487 & -1.2600 & -1.1621 & -0.1887 & -0.2866 & -0.0978 \\
\hline LEVERAGE & 1562.9870 & 1283.0640 & 534.4561 & 279.9239 & 1028.5310 & 748.6074 \\
\hline PROFITABILITY & 0.0210 & 0.0435 & 0.0552 & -0.0225 & $-0.0342 * *$ & -0.0117 \\
\hline LIQUIDITY & 0.5987 & 0.3561 & 0.3404 & $0.2426 * *$ & $0.2583 * *$ & 0.0157 \\
\hline SOLVENCY & 51.3924 & 61.2809 & 63.9856 & -9.8885 & -12.5932 & -2.7047 \\
\hline
\end{tabular}

$* * *, * *, *$ indicate two-sided significance at 1,5 and 10 percent levels, respectively.

$\mathrm{n}=173$

Table 4 presents the results of paired t-test of a balanced panel between 1 year, 2 years and 3 years prior to liquidation of earnings smoothing and bankruptcy risk-related variables. The definition for all variables can be found in Appendix A.

Meanwhile, firms' PROFITABILITY and SOLVENCY are the highest in 3 years prior to the liquidation as compared to one and two years prior to liquidation while firms' LEVERAGE and LIQUIDITY are the highest in the one year prior to liquidation as compared to two and three years prior to liquidation, as expected. However, only PROFITABILITY and LIQUIDITY show statistically significant differences. This finding is similar to Akbar et al. (2013) who find that private firms hold more cash when they are in distressed - to hedge against the effect of bankruptcy risk.

\section{Conclusion}

This study examines how earnings smoothing affects the likelihood of bankruptcy risk in liquidating private firms in UK. Firms which are in liquidation from 2012 to 2017 are used as the sample. It is found that earnings smoothing is negatively associated with bankruptcy risk which indicates that private firms engage less with earnings smoothing as they are getting more distressed. Further examination reveals that this relationship is influenced by creditors monitoring activities, since firms were getting more credit when they are in distressed. Firms were getting more credit because they want to hold more cash (liquidity), as their strategy to hedge against distressed times.

The results emphasize how little we know about earnings management practices, specifically earnings smoothing, in private firms. Therefore, more researches are needed to enlighten our understanding on this matter. Future researches might want to consider the role of real earnings smoothing in private firms since this earnings behaviour is more prevalent in the real accounting practice. 
Table 5. Earnings smoothing prior liquidation

\begin{tabular}{|c|c|c|c|c|c|c|c|}
\hline \multirow[b]{2}{*}{ Variable } & \multirow[b]{2}{*}{$\underline{\text { Expected sign }}$} & \multicolumn{2}{|c|}{1 year prior } & \multicolumn{2}{|c|}{2 year prior } & \multicolumn{2}{|c|}{3 year prior } \\
\hline & & Coef. & $\mathbf{t}$ & Coef. & $\mathbf{t}$ & Coef. & $\mathbf{t}$ \\
\hline LEVERAGE & negative & $-0.0000^{* * *}$ & -5.45 & $-0.0000^{* * *}$ & -5.35 & $-0.0001 * * *$ & -5.02 \\
\hline PROFITABILITY & positive & -0.0088 & -0.21 & 0.1874 & 0.39 & $1.2337 * *$ & 1.97 \\
\hline LIQUIDITY & positive & 0.0066 & 0.75 & 0.0816 & 0.97 & 0.1216 & 0.89 \\
\hline SOLVENCY & positive & -0.0001 & -1.25 & 0.0000 & 0.52 & 0.0005 & 1.19 \\
\hline INDUSTRY FIXED EFFECT & & -0.0061 & -1.20 & -0.0086 & -1.54 & -0.0107 & -1.58 \\
\hline CONSTANT & & $-0.8296^{* *}$ & -3.02 & -0.7725 & -2.54 & $-0.7049 *$ & -1.95 \\
\hline R-squared & & 0.0872 & & 0.1039 & & 0.1334 & \\
\hline Adjusted R-squared & & 0.0747 & & 0.0887 & & 0.1147 & \\
\hline$n$ & & 372 & & 300 & & 237 & \\
\hline
\end{tabular}

\section{References}

Acharya, V., \& Lambrecht, B. M. (2015). A Theory of Income Smoothing When Insiders Know More Than Outsiders. Review of Financial Studies, 28(9), 2534-2574. Retrieved from https://doi.org/10.1093/rfs/hhv026

Aghion, P., \& Bolton, P. (1992). An Incomplete Contracts Approach to Financial Contracting. Review of Economic Studies, 59, 473-494. Retrieved from https://doi.org/10.2307/2297860

Akbar, S., Rehman, S. ur, \& Ormrod, P. (2013). The Impact of Recent Financial Shocks on the Financing and Investment Policies of UK Private Firms. International Review of Financial Analysis, 26, 59-70. http://doi.org/10.1016/j.irfa.2012.05.004

Altman, E. (1983). Corporate Financial Distress: A Complete Guide to Predicting, Avoiding and Dealing with Bankruptcy. John Wiley \& Sons.

Altman, E., \& Sabato, G. (2007). Modelling Credit Risk for SMEs: Evidence from the U. S. Market. Abacus, 43(3), 332-357. http://doi.org/10.1111/j.1467-6281.2007.00234.x

Amiram, D., \& Owens, E. (2018). Sign Reversal in the Relation between Income Smoothing and Cost of Debt. Journal of Business Finance \& Accounting, 45(1-2), 40-71. http://doi.org/10.1111/jbfa.12295

Arya, A., Glover, J. C., \& Sunder, S. (2003). Are Unmanaged Earnings Always Better for Shareholders? Accounting Horizons, 17, 111-116.

Ball, R., \& Shivakumar, L. (2005). Earnings quality in UK private firms : comparative loss 
recognition timeliness \$, 39, 83-128. http://doi.org/10.1016/j.jacceco.2004.04.001

Bellovary, J., Giacomino, D., \& Akers, M. (2007). A Review of Bankruptcy Prediction Studies: 1930-present. Journal of Financial Education, 33(Winter), 1-42. Retrieved from http://www.jstor.org/stable/41948574

Bhattacharya, U., Daouk, H., \& Welker, M. (2003). The World Price of Earnings Opacity. The Accounting Review, 78(3), 641-678. Retrieved from https://doi.org/10.2308/accr.2003.78.3.641

Bigus, J., \& Häfele, S. (2016). Shareholder Loans and Earnings Smoothing - Empirical Findings from German Private Firms. European Accounting Review. http://doi.org/10.1080/09638180.2016.1229206

Burgstahler, D. C., Hail, L., \& Leuz, C. (2006). The Importance of Reporting Incentives: Earnings Management in European Private and Public Firms. Accounting Review, 81(5), 983-1016. http://doi.org/10.2308/accr.2006.81.5.983

Cahan, S. F., Liu, G., \& Sun, J. (2008). Investor Protection, Income Smoothing and Earnings Informativeness. Journal of International Accounting Research, 7(1), 1-24. Retrieved from https://doi.org/10.2308/jiar.2008.7.1.1

Chen, C., Kim, J. B., \& Yao, L. (2017). Earnings Smoothing: Does It Exacerbate or Constrain Stock Price Crash Risk? Journal of Corporate Finance, 42, 36-54. http://doi.org/10.1016/j.jcorpfin.2016.11.004

Coppens, L., \& Peek, E. (2005). An Analysis of Earnings Management by European Private Firms. Journal of International Accounting, Auditing and Taxation, 14, 1-17. http://doi.org/10.1016/j.intaccaudtax.2005.01.002

Das, S., Hong, K., \& Kim, K. (2013). Earnings Smoothing, Cash Flow Volatility, and CEO Cash Bonus. Financial Review, 48(1), 123-150. http://doi.org/10.1111/j.1540-6288.2012.00349.x

Demerjian, P. R., Donovan, J., \& Lewis-Western, M. F. (2017). Income Smoothing and Debt Covenants: Evidence from Technical Default. SSRN Electronic Journal. http://doi.org/10.2139/ssm.2745631

Dou, Y., Hope, O. K., \& Thomas, W. B. (2013). Relationship-Specificity, Contract Enforceability, and Income Smoothing. The Accounting Review, 88(5), 1629-1656. Retrieved from https://doi.org/10.2308/accr-50489

Francis, J., LaFond, R., Olsson, P. M., \& Schipper, K. (2005). The Market Pricing of Accruals Quality. Journal of Accounting and Economics, 39(2), 295-327. Retrieved from https://doi.org/10.1016/j.jacceco.2004.06.003

Franz, D. R., HassabElnaby, H. R., \& Lobo, G. J. (2014). Impact of Proximity to Debt Covenant Violation on Earnings Management. Review of Accounting Studies, 19(1), 473-505. Retrieved from https://doi.org/10.1007/s11142-013-9252-9 
Gassen, J., \& Fülbier, R. U. (2015). Do Creditors Prefer Smooth Earnings? Evidence from European Private Firms. Journal of International Accounting Research, 14(2), 151-180. http://doi.org/10.2308/jiar-51130

Gaver, J. J., Gaver, K. M., \& Austin, J. R. (1995). Additional Evidence on Bonus Plans and Income Management. Journal of Accounting and Economics, 19(1), 3-28. Retrieved from https://doi.org/10.1016/0165-4101(94)00358-C

Goel, A. M., \& Thakor, A. V. (2003). Why Do Firms Smooth Earnings? Journal of Business, 76(1), 151-192. Retrieved from http://www.jstor.org/stable/10.1086/344117

Graham, J. R., Harvey, C. R., \& Rajgopal, S. (2005). The Economic Implications of Corporate Financial Reporting. Journal of Accounting and Economics, 40(1), 3-73. Retrieved from https://doi.org/10.1016/j.jacceco.2005.01.002

Grant, J., Markarian, G., \& Parbonetti, A. (2009). CEO Risk-Related Incentives and Income Smoothing. Contemporary Accounting Research, 26(4), 1029-1065. http://doi.org/10.1506/car.26.4.2

Healy, P. (1985). The Effect of Bonus Schemes on Accounting Decisions. Journal of Accounting and Economics, 7(1-3), 85-107. Retrieved from https://doi.org/10.1016/0165-4101(85)90029-1

Hope, O., Thomas, W., \& Vyas, D. (2011). Financial credibility, ownership, and financing constraints in private firms. Journal of International Business Studies, 42(7), 935-957. http://doi.org/10.1057/jibs.2011.23

Hope, O., \& Vyas, D. (2017). Private company finance and financial reporting. Accounting and Business Research, 47(5), 506-537. http://doi.org/10.1080/00014788.2017.1303963

Jayaraman, S. (2008). Earnings Volatility, Cash Flow Volatility and Informed Trading. Journal of Accounting Research, 46(4), 809-851. Retrieved from https://doi.org/10.1111/j.1475-679X.2008.00293.x

Jung, B., Soderstrom, N., \& Yang, Y. S. (2013). Earnings Smoothing Activities of Firms to Manage Credit Ratings. Contemporary Accounting Research, 30(2), 645-676. http://doi.org/10.1111/j.1911-3846.2012.01170.x

Khurana, I. K., Pereira, R., \& Zhang, E. (2017). Is Real Earnings Smoothing Harmful? Evidence from Firm-Sspecific Stock Price Crash Risk. Contemporary Accounting Research. http://doi.org/10.1111/ijlh.12426

Kirschenheiter, M., \& Melumad, N. D. (2002). Can "Big Bath" and Earnings Smoothing Co-Exist as Equilibrium Financial Reporting Strategies? Journal of Accounting Research, 40(3), 761-796. Retrieved from https://doi.org/10.1111/1475-679X.00070

Kothari, A. S. P., Shu, S., \& Wysocki, P. D. (2009). Do Managers Withhold Bad News? Journal of Accounting Research, 47(1), 241-276. http://doi.org/10.1111/j.1475-679X.2008.00318.x 
Li, S., \& Richie, N. (2016). Income Smoothing and the Cost of Debt. China Journal of Accounting Research, 9(3), 175-190. Retrieved from https://doi.org/10.1016/j.cjar.2016.03.001

Maffet, M. (2012). Financial Reporting Opacity and Informed Trading by International Institutional Investors. Journal of Accounting and Economics, 54(2), 201-220. Retrieved from https://doi.org/10.1016/j.jacceco.2012.09.002

Moses, O. D. (1987). Income Smoothing and Incentives: Empirical Tests using Accounting Changes. The Accounting Review, 358-377. http://doi.org/http://www.jstor.org/stable/247931

Ronen, J., \& Sadan, S. (1981). Smoothing Income Numbers: Objectives, Means and Implications. Boston: Addison-Wesley Publishing Company.

Saleh, N. M., \& Ahmed, K. (2005). Earnings Management of Distressed Firms during Debt Renegotiation. Accounting and Business Research, 35(1), 69-86. Retrieved from https://doi.org/10.1080/00014788.2005.9729663

Sankar, M. R., \& Subramanyam, K. R. (2001). Reporting Discretion and Private Information Communication through Earnings. Journal of Accounting Research, 39(2), 365-386. Retrieved from https://doi.org/10.1111/1475-679X.00017

Shabani, N. A., \& Sofian, S. (2018). Earnings Smoothing as Information Signaling or Garbling: A Review of Literature. Asian Journal of Finance \& Accounting, 10(1), 131-142. http://doi.org/10.5296/ajfa.v10i1.12768

Sweeney, A. P. (1994). Debt-Covenant Violations and Managers' Accounting Responses. Journal of Accounting and Economics1, 17(3), 281-308. Retrieved from https://doi.org/10.1016/0165-4101(94)90030-2

Trueman, B., \& Titman, S. (1988). An Explanation for Accounting Income Smoothing. Journal of Accounting Research, 26, 127-139. Retrieved from http://www.jstor.org/stable/2491184

Tucker, J. W., \& Zarowin, P. A. (2006). Does Income Smoothing Improve Earnings Informativeness? The Accounting Review, 81(1), 251-270. Retrieved from https://doi.org/10.2308/accr.2006.81.1.251 


\section{Appendix A - Definition of variables}

\begin{tabular}{|c|c|}
\hline Variable & Definition \\
\hline Z” SCORE & $\begin{array}{l}Z \text { ' score }=6.56 * \mathrm{X}_{1}+3.26 * \mathrm{X}_{2}+6.72 * \mathrm{X}_{3}+1.05^{*} \mathrm{X}_{4} \\
\text { Where: } \\
\mathrm{X}_{1} \text { is working capital scaled by total assets } \\
\mathrm{X}_{2} \text { is retained profit scaled by total assets } \\
\mathrm{X}_{3} \text { is EBIT scaled by total assets } \\
\mathrm{X}_{4} \text { is shareholders' equity scaled by total assets }\end{array}$ \\
\hline SMOOTH & $\begin{array}{l}\text { Smooth = STD_NET_INCOME/STD_CASH_FLOW } \\
\text { Where: } \\
\text { STD_NET_INCOME is standard deviation of net income, } \\
\text { scaled by lagged total assets } \\
\text { STD_CASH_FLOW is standard deviation of cash flow } \\
\text { from operation, scaled by lagged total assets } \\
\text { Standard deviation of net income and cash flow from } \\
\text { operation is measured using } 3,4 \text { and } 5 \text { years data }\end{array}$ \\
\hline LEVERAGE & Current liabilities divided with shareholder's equity \\
\hline PROFITABILITY & EBITDA divided with total assets \\
\hline LIQUIDITY & Cash divided with total assets \\
\hline SOLVENCY & Current liabilities divided with inventory \\
\hline $\begin{array}{l}\text { INDUSTRY } \\
\text { FIXED-EFFECT }\end{array}$ & Two digit SIC code \\
\hline
\end{tabular}

\section{Copyright Disclaimer}

Copyright for this article is retained by the author(s), with first publication rights granted to the journal.

This is an open-access article distributed under the terms and conditions of the Creative Commons Attribution license (http://creativecommons.org/licenses/by/3.0/). 